Lev, M. (1959). J. gen. Microbiol. 20, 697-703

\title{
The Growth-Promoting Activity of Compounds of the Vitamin K Group and Analogues for a Rumen Strain of Fusiformis nigrescens
}

\author{
BY M. LEV \\ Bacteriology Department, National Institute for Research in Dairying, \\ University of Reading
}

SUMMARY: With a strain of Fusiformis nigrescens as test organism, the potencies of compounds of the vitamin $\mathrm{K}$ group were estimated, and the results compared with those from animal assay techniques. The compounds showed in the main the same relative activity for the micro-organism as for higher animals, with two exceptions: 1:4-naphthoquinone was highly active for $F$. nigrescens but is inactive for animals; phthiocol, which is active for animals, inhibited the response of $F$. nigrescens to menaphthone, i.e. phthiocol acted as an anti-vitamin $\mathrm{K}$ for the micro-organism. Most of the compounds tested were toxic in the range $1-5 \mu \mathrm{g}$. $/ \mathrm{ml}$.; vitamins $K_{1}, K_{2}$ and a water soluble form of menaphthone (menaphthone bisulphite) were relatively less toxic.

The synthesis of vitamin $\mathrm{K}$ by certain bacteria is well known, and Woolley \& McCarter (1940) reported a stimulation of the growth of Mycobacterium paratuberculosis (Johne's bacillus) by menaphthone and phthiocol. However, subcultures of this organism in the basal medium supplemented by the vitamin did not always show growth, and Glavind \& Dam (1948), using another strain of $M$. paratuberculosis, were unable to confirm the results of Woolley \& McCarter. Large amounts of synthetic forms of vitamin $\mathbf{K}$ are toxic for microorganisms (Armstrong, Spink \& Kahnke, 1943). This non-specific toxicity led Almquist (1954) to doubt the feasibility of a microbiological assay for vitamin $\mathbf{K}$. However, the requirement for vitamin $\mathbf{K}$ shown by a rumen strain of Fusiformis nigrescens (Lev, 1958) suggested the use of this organism to estimate the relative potencies of analogues of this vitamin.

\section{METHODS}

Organism. A strain of Fusiformis nigrescens isolated from bovine rumen contents (Lev, 1958) was used. It is a strict anaerobe, and requires blood in addition to vitamin $\mathrm{K}$. The medium used in the assay procedure was meat extract broth (MEB), which consisted of: meat extract (Difco) 3 g.; $\mathbf{N a C l} 5$ g.; peptone (Difco) $10 \mathrm{~g}$; ; distilled water to $1 \mathrm{l}$. The medium was adjusted to $\mathrm{pH} 7 \cdot 5$, distributed in $10 \mathrm{ml}$. amounts, and autoclaved for $15 \mathrm{~min}$. at $15 \mathrm{lb} . /$ sq.in.

Human blood was used in the majority of experiments; horse blood was also used. The blood was centrifuged slowly. A 1/35 dilution of red blood cells was made in distilled water and $0 \cdot 1 \mathrm{ml}$. was added to each tube of MEB. This dilution of laked blood, with vitamin $\mathbf{K}$, allowed good growth of the organism without interfering with optical density readings. 
The compounds to be assayed were made up as $10 \mathrm{mg} . / \mathrm{ml}$. solutions in absolute ethanol and subsequent dilutions, which were either solutions or emulsions, were made in distilled water. A typical assay procedure was as follows. Tubes of MEB were heated in a boiling water bath for $10 \mathrm{~min}$., cooled and $0.1 \mathrm{ml}$. of the diluted laked red cells added. Dilutions of vitamin $\mathrm{K}$ to give final concentrations of 0.05-10 $\mu \mathrm{g} . / \mathrm{ml}$. were added and the tubes were inoculated with $0.05 \mathrm{ml}$. of a two-day culture of Fusiformis nigrescens in MEB+ laked red cells $+0.5 \mu \mathrm{g}$. menaphthone $/ \mathrm{ml}$. Control tubes included in each assay consisted of MEB + red cells. The tubes were placed in an anaerobic jar and incubated at $39^{\circ}$ in an atmosphere of $90 \%(v / v) \mathrm{H}_{2}+10 \%(\mathrm{v} / \mathrm{v}) \mathrm{CO}_{2}$. After incubation for 2 days, optical density readings were taken at $520 \mathrm{~m} \mu$ with a Beckman spectrophotometer. In one experiment readings were taken with a Hilger Spekker absorptiometer using a no. 7 filter.<smiles>O=C1C=CC(=O)c2ccccc21</smiles>

1<smiles>CC1=C(O)C(=O)c2ccccc2C1=O</smiles><smiles>CC1=CC(=O)c2ccccc2C1=O</smiles>

2<smiles>CC1=C(C)C(=O)c2ccccc2C1=O</smiles>

3<smiles>Cc1cc(N)c2ccccc2c1O</smiles><smiles>[R]C1=C(C)C(=O)c2ccccc2C1=O</smiles>

Fig. 1. Analogues etc. of vitamin $\mathrm{K}$ group tested.

(1) 1:4-naphthoquinone; (2) menaphthone; (3) 2:3-dimethylnaphthoquinone ;

(4) vitamin $K_{5}$;

(5) phthiocol;<smiles>[R]C1=C(O)C(=O)c2ccccc2C1=O</smiles>

(6)<smiles></smiles>

$\mathbf{R}=-\left(\mathrm{CH}_{2}\right)_{9}-\mathrm{C}_{6} \mathrm{H}_{11}$ (cyclohexyl) $\mathrm{M} 1953$;

$\mathrm{R}=-\left(\mathrm{CH}_{2}\right)_{3}-\mathrm{C}_{6} \mathrm{H}_{11}$ (cyclohexyl) M1916;

(7)



The structures of the compounds tested are shown in Fig. 1.

\section{RESULTS}

A characteristic of all assays was the toxicity of the used compounds, beyond a critical concentration. Compounds generally became toxic at concentrations greater than those at which maximum growth occurred (Figs. 2-6) 
and is indicated where the graphs end. Vitamins $K_{1}$ and $K_{2}$ were relatively non-toxic (Fig. 2) and the water soluble form of menaphthone (menaphthone bisulphite) was less toxic than the fat soluble menaphthone, i.e. in assays menaphthone was toxic in amounts greater than $1 \mu \mathrm{g} . / \mathrm{ml}$., whereas the bisulphite compound was not toxic at $10 \mu \mathrm{g} . / \mathrm{ml}$.

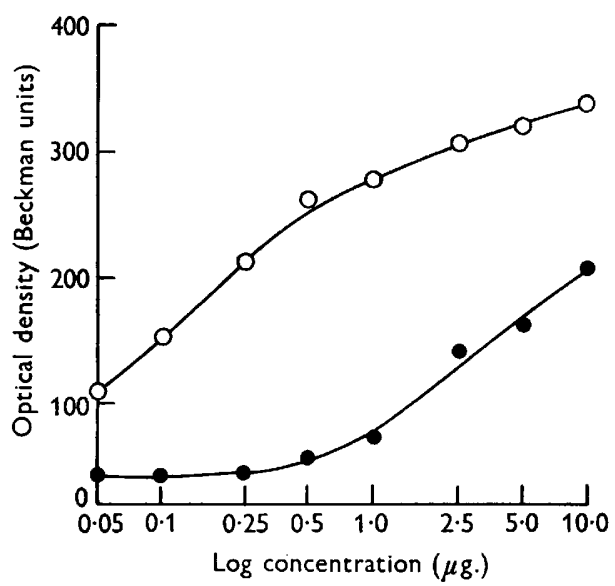

Fig. 2

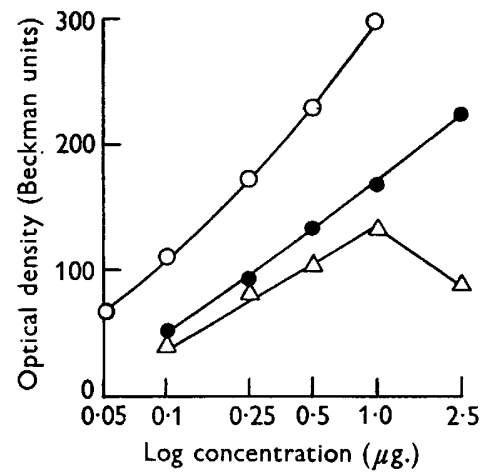

Fig. 3

Fig. 2. Comparative activities of vitamins $K_{1}(O)$ and $K_{2}(\bullet)$.

Fig. 3. Comparative activities of (I) 1:4-naphthoquinone (O), (II) menaphthone (O) and (III) 2:3 dimethyl 1:4 naphthoquinone $(\triangle)$.

The results of the comparative activity of vitamin K-like compounds for Fusiformis nigrescens are compared with their reported activities for animals in Table 1.

Assays of 1:4-naphthoquinone, 2-methyl (menaphthone) and 2:3-dimethyl derivatives are shown in Fig. 3. 1:4-Naphthoquinone was more effective than

Table 1. Comparative activity of the vitamin $K$ group compounds and analogues for animals and for Fusiformis nigrescens

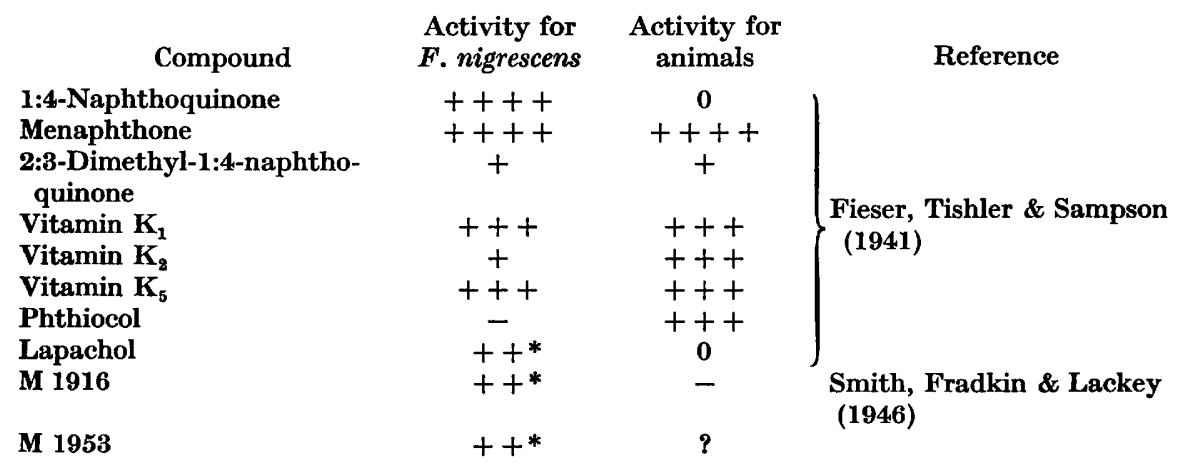

++++ , High activity (= menaphthone); - , anti-vitamin $\mathrm{K}$ activity; 0 , no activity; ?, activity not known.

* Stimulatory at low concentrations. 
menaphthone, which had greater activity than the 2:3-dimethyl derivative; 1:2-naphthoquinone showed slight activity. Menaphthone appears to be $1 \cdot 4-2 \cdot 5$ times as active as vitamin $K_{1}$ when equal weights of the two compounds are used. When compared on an equimolar basis vitamin $K_{1}$ was 1.6 times more potent than menaphthone. Vitamin $K_{2}$ showed less than one-tenth of the activity of vitamin $\mathbf{K}_{\mathbf{1}}$ in promoting the growth of Fusiformis nigrescens. Phthiocol was inactive; this analogue was reported (Fieser, Tishler \& Sampson, 1941) to have vitamin $K$ activity in animals, but less than menaphthone. It

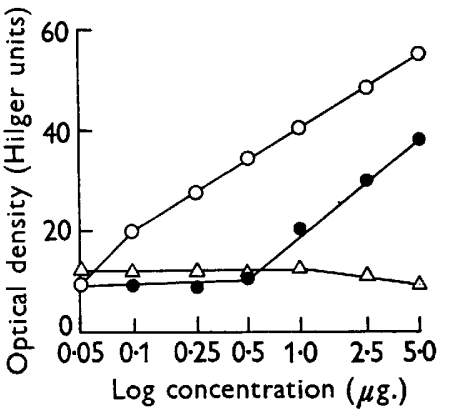

Fig. 4



Fig. 5

Fig. 4. Inhibition by phthiocol of growth response of $F$. nigrescens to menaphthone. O, Menaphthone; 0 , menaphthone $+0.5 \mu \mathrm{g} . / \mathrm{ml}$. phthiocol; $\Delta$, phthiocol.

Fig. 5. Comparative activities of $M 1953(O), M 1916(\triangle)$ and lapachol (๑).

was originally isolated from Mycobacterium tuberculosis, probably as a degradation product of vitamin $K_{1}$ (Karrer, 1950). However, as can be seen from Fig. 4 , it has no vitamin $\mathrm{K}$ activity for $\boldsymbol{F}$. nigrescens. The structural similarity of phthiocol to menaphthone, together with the lack of a growth-promoting activity, suggested that this substance may act as an anti-vitamin for F. nigrescens. This was shown (Fig. 4) when a constant amount of phthiocol, to give a final concentration of $0.5 \mu \mathrm{g} . / \mathrm{ml}$., was added to a range of menaphthone concentrations. Stimulation of growth occurred when the amount of menaphthone was greater than that of phthiocol. No attempt was made to determine whether this inhibition was competitive.

The derivatives of phthiocol tested, compounds M1953, M1916 and lapachol (Fig. 5), showed high activity at low concentrations, but became toxic at relatively low levels. Compound M1916 has haemorrhagic properties in rats (Smith, Fradkin \& Lackey, 1946). Because of this growth-stimulating power of an anti-vitamin $\mathbf{K}$ compound for Fusiformis nigrescens, it was of interest to determine whether other compounds with known anti-vitamin $\mathbf{K}$ activity could behave in a similar manner. Dicoumarol \& Warfarin were investigated, but did not stimulate $\boldsymbol{F}$. nigrescens. In another series of experiments (Lev, 1958), dicoumarol was found to inhibit competitively the response of $\boldsymbol{F}$. nigrescens to menaphthone.

Vitamin $\mathrm{K}_{5}$ (4-amino- 2-methyl- 1-naphthol) had activity for Fusiformis nigrescens, although it was not as active as menaphthone (Fig. 6). Richert 
(1944) showed that the chick converts vitamin $K_{5}$ to menaphthone, and it seems possible that this conversion may also be effected by $\boldsymbol{F}$. nigrescens.

Several reports, e.g. Prosperi \& Lottini (1949), have suggested an interaction between vitamin $\mathbf{E}$ and vitamin $\mathrm{K}$. An experiment was made to determine whether vitamin $\mathbf{E}$ (DL- $\alpha$-tocopherol) stimulated Fusiformis nigrescens and also whether any interaction occurred between $\alpha$-tocopherol and vitamin



Fig. 6. Comparative activities of menaphthone $(O)$ and vitamins $K_{5}(\Theta)$ and $K_{1}(\triangle)$ on growth response of Fusiformis nigrescens.

$\mathrm{K}_{\mathbf{1}}$. The results were negative; $\alpha$-tocopherol neither stimulated the growth of $F$. nigrescens, nor had it any effect on the response of this organism to vitamin $\mathrm{K}_{1}$. In this experiment, because of the opacity of the suspension of $\alpha$-tocopherol in the medium, additional controls consisting of dilutions not inoculated with the test organism were made.

\section{DISCUSSION}

The results presented here suggest a useful microbiological method for estimating vitamin $K$ and the potencies of the compounds tested follow in the main the same order as that found by animal assay techniques. However, the specificity of Fusiformis nigrescens for the vitamin $\mathbf{K}$ group differs in two major respects from that of animals; (a) 1:4-naphthoquinone is highly active for the micro-organism but shows no activity in the chick assay; $(b)$ phthiocol, which shows appreciable vitamin $\mathbf{K}$ activity for animals, antagonizes the growth stimulation by menaphthone of $F$. nigrescens. The micro-organism thus shows a greater specificity for vitamin $K$ with respect to phthiocol than higher animals, which is the reverse of what is commonly found in microbiological assays.

Vitamin $K_{1}$ was found by Almquist \& Klose (1940) to be 1.25 to 1.5 times as potent as vitamin $K_{2}$ when compared on a molar basis. The difference between the chick and microbiological assays may be due to the greater insolubility of vitamin $K_{2}$ and the subsequent difficulty in absorption of the 
vitamin by the micro-organism. Compound M1916, which shows haemorrhagic (anti-vitamin $\mathrm{K}$ ) properties when given to rats, has a high vitamin $\mathrm{K}$ activity for Fusiformis nigrescens at very low concentrations. This does not necessarily indicate a difference in specificity between $\boldsymbol{F}$. nigrescens and rats for compound M1916, as rats fed this compound and a vitamin $\mathrm{K}$-deficient diet were not included in the experiments of Smith et al. (1946).

The toxicity to Fusiformis nigrescens of many of the compounds tested in concentrations greater than 1-5 $\mu \mathrm{g} . / \mathrm{ml}$. is of interest. Vitamin $K_{1}$ is relatively non-toxic, as would be expected, because it is present in large amounts in the grass content of the bovine rumen, from which this strain of $F$. nigrescens was originally isolated, and may also be, as Fieser, Tishler \& Sampson (1941) suggested, the complete form of the vitamin which is synthesized from menaphthone. This non-toxic character of vitamin $K_{1}$ compared with the synthetic forms of the vitamin for $\boldsymbol{F}$. nigrescens can be seen in the data of Shimkin (1941) and Ansbacher, Corwin \& Thomas (1942) for a variety of animals.

A major disadvantage in the microbiological assay of fat soluble substances is the relative insolubility of the compounds in water, together with the possibility that solubility may affect the potency of a compound. That this possibility is not wholly true is suggested by the fact that vitamin $K_{1}$, a relatively insoluble form of the vitamin, is readily metabolized. Most of these substances in concentrations greater than $25 \mu \mathrm{g} . / \mathrm{ml}$. increase the opacity of the medium, which would make the assay of high concentrations of compounds with low activity impracticable. Compared with other microbiological assay techniques the method described is somewhat lengthy because of the medium and the anaerobic character of the test organism. Experiments are in progress to simplify the medium and to develop the assay into a practical method for the estimation of the vitamin $\mathbf{K}$ group.

The author's thanks are due to: Dr Martin Forbes of the Department of Microbiology, Temple University, Pa., for much encouragement and help during the course of this work; to Dr E. A. Doisy of the St Louis School of Medicine, St Louis, Mo., for supplying vitamin $\mathrm{K}_{2}$; and to Professor L. F. Fieser, of the Department of Chemistry, Harvard University, Cambridge, Mass., for suggesting the use of, and supplying, dimethylnaphthoquinone and derivatives of phthiocol.

\section{REFERENCES}

Almquist, H. J. (1954). The Vitamins, p. 417. New York: Academic Press Inc. Almquist, H. J. \& Klose, A. A. (1940). Comparative activities of certain antihaemorrhagic compounds. Proc. Soc. exp. Biol., N.Y. 45, 55.

Ansbacher, S., Corwin, W. C. \& Thomas, B. G. H. (1942). Toxicity of menadione, menadiol and esters. J. Pharmacol. 75, 111.

Armstrong, W. D., Spink, W. W. \& Kahnke, J. (1943). Antibacterial effects of quinones. Proc. Soc. exp. Biol., N.Y. 53, 230.

Fieser, L. F., Tishler, M. \& Sampson, W. L. (1941). Vitamin $\mathrm{K}$ activity and structure. J. biol. Chem. 137, 659.

Glavind, J. \& Dam, H. (1948). Factors affecting the growth of Johne's bacillus. Physiol. Plant. 1, 1.

Karrer, P. (1950). Organic Chemistry, 4th English ed., p. 588. London: Elsevier Publishing Company, Inc. 
LEv, M. (1958). Apparent requirement for vitamin $\mathrm{K}$ of rumen strains of Fusiformis nigrescens. Nature, Lond. 181, 203.

Prosperi, P. \& Lottini, A. (1949). Nuovi orizzonti nel campo della diatesi emorragische: La vitamina E. Riv. Clin. pediat. $47,731$.

Richert, D. A. (1944). Biological conversion of active non-quinones of vitamin $K$ to the quinone form. J. biol. Chem. 154, 1.

ShImkin, M. B. (1941). Toxicity of naphthoquinones with vitamin $\mathrm{K}$ activity in mice. J. Pharmacol. 71, 210.

Smith, C. C., Fradkin, R. \& Lackey, M. D. (1946). A haemorrhagic syndrome induced by derivatives of 3 hydroxy $1: 4$ naphthoquinone. Proc. Soc. exp. Biol., N.Y. $61,398$.

Woolley, D. W. \& McCarter, J. R. (1940). Antihaemorrhagic compounds as growth factors for the Johne's bacillus. Proc. Soc. exp. Biol., N.Y. 45, 357.

(Received 10 December 1958) 